Editorial

\title{
Alzheimer vaccine: a theme of notable contraversy
}

\author{
Volume 2 Issue 5 - 2016 \\ Ibrahim MSAW Shnawa \\ University of Qasim, Iraq
}

\section{Editorial}

Ageing genetic and environmental factors are among the basic etiologies of dementia. Dementia are of several types .Among which is the Alzheimer disease (AD). ${ }^{1}$

$\mathrm{AD}$ accounts for 60 to $80 \%$ of dementia cases. A sum of four genes; Presenilin 1/chromosome 14, Presenilin 2/chromosome 1, Amyloid Precursor protein/chromosome 21, and Apolipoprotein e/ chromosome 19, are responsible for the manifestation of AD which happened in fourth decade of human age. ${ }^{2}$ The patho-biology of AD can be briefed as progressive nerve cell death resulting from the accumilation of amyloid protein beta plaques, around nerve cell body and neuro-fibrilar tangles Tau within the axon of the nerve cells. ${ }^{1}$

Since about two decades, neuro-scientists and neuro- immnologists have been attempting to develop a vaccine design that might be helpful to prevent and/or treat $\mathrm{AD}$. The primordial $\mathrm{AD}$ vaccine has been made from Amyloid Beta protein 2001 and extend to 2013, tau protein 2016, (Jones R, Bath; UK). ${ }^{3-8}$ Variable degrees of foundations that have been ranged from failure to promising in various research groups all-over the world at the level of development and pre-licensed evaluations in laboratory Animals Table $1 .^{4-8}$ Among several groups of research workers, one will initiate preclinical trail phase one within the coming three years. ${ }^{3}$ These attempts have been targeting amyloid protein B and tau in separate as prime boost protocol or combined immunogen program with presence of certain adjuvants. ${ }^{3}$ The chronology of scientific achievements towards developing $\mathrm{AD}$ vaccine design was Mapped in the Table $1 .^{4-8}$ The evaluation parameters for a vaccine were depictedin Table $2^{9}$ in a comparative manner with an infectious and cancerous disease just to through a light on the core facts of Alzheimer vaccine. As a scientific holdings the B amyloid or tau vaccines as well as their specific monoclonal antibodies gain success in laboratory animal models but in preclinical trials their results is a matter of debates .If the reality is somewhat far from being reached by current days research, one can propose; 1-Initiation of local CNS immune response to clear up amyloid beta and tau., 2-Initiation of glial cell system to engulf the destroyed neuron cells. ${ }^{10-13}$ The use of monoclonal antibodies specific for B amyloid and /tau to form complexes with the available complement that can be cleared up through pinocytosis, 4-Initiating apoptosis process, ${ }^{14,15}$ to defective neuron cells followed by engulfment by the local resident or migratory macrophages. ${ }^{13}$ In case of Alzheimers disease, the need for a vaccine is eligible for both prevention and therapy. The development of preventive vaccine is being of prime importance, followed by the therapeutic vaccine. Hopes that the coming few years, scientists will disclose promising vaccines for both purposes.

Table I Chronology of Alzheimer vaccine achievements

\begin{tabular}{llll}
\hline Date & Reference & Vaccine target & Mechanisms \\
\hline 2001 & $\begin{array}{l}\text { Australian centre of } \\
\text { Alzheimers Disease }\end{array}$ & $\begin{array}{l}\text { Passive immunization with } \\
\text { immunoglobulin }\end{array}$ & Success in very small group of eight patients \\
2001 & 4 & B42 peptide vaccine & Reduce memory loss, amyloid B reduction in mice \\
2002 & 5 & Beta amyloid reagent .Arc I792 & $20 \%$ immunized,other20\% got brain inflammation \\
2002 & 6 & $\begin{array}{l}\text { Beta amyloid vaccine or its } \\
\text { specific antibody }\end{array}$ & Neutralize the pathogenic effect of beta amyloid \\
2012 & 7 & B amyloid vaccine design with & With adjuvant stimulate the immune system to produce immune \\
2013 & 8 & CADI06 & B2 pesponse \\
2015 & Pickett, Alzheimers Society & Tau tangle antigen vaccine & Semove B amyloid by phagocytes
\end{tabular}

Table 2 Comparative View to Vaccine criteria for concern of Alzheimer vaccine

\begin{tabular}{llll}
\hline NIH criteria9 & $\begin{array}{l}\text { Vaccine for a Vaccine } \\
\text { Preventable Infectious } \\
\text { Disease }\end{array}$ & $\begin{array}{l}\text { Vaccine for a Vaccine } \\
\text { Preventable and Treatable } \\
\text { Cancer }\end{array}$ & $\begin{array}{l}\text { Vaccine for Alzheimer } \\
\text { Disease }\end{array}$ \\
\hline Understanding disease & Understandable & Relatively understandable & Observable understanding \\
Understanding disease agent & Understandable & Viral, genetic, environmental & Observable; aging, genetic and environmental \\
\hline
\end{tabular}


Table Continued...

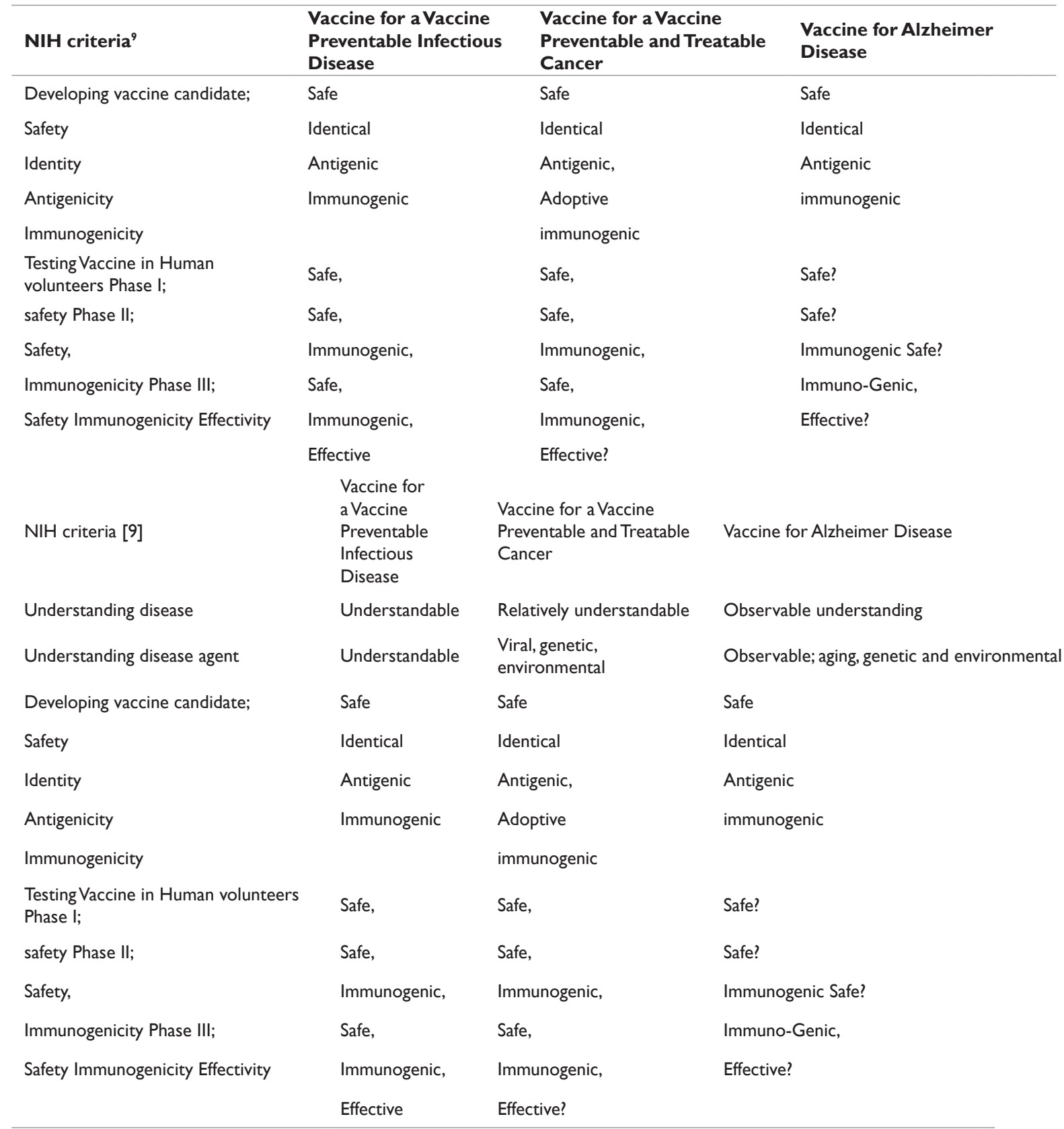

\section{Acknowledgments}

None.

\section{Conflicts of interest}

Author declares there are no conflicts of interest.

\section{Funding}

None.

\section{References}

1. https://en.wikipedia.org/wiki/Alzheimer\%27s_disease

2. Best B. Alzheimers Disease: Molecular mechanisms. 2013.

3. DavtyanH, ZagorskiK, RagapakshH, t al. Alzheimer's disease $\operatorname{Advax}(\mathrm{CpG})$-adjuvanated MultiTEP. Based dual and single vaccine induce high titre antibodies against various forms of tau and $\mathrm{AB}$ pathological molecules. Sci Rep. 6:28912.

4. Growdn JH. A Guide TO Cop with ALzheimers Disease, Harvard Health Publications. 2015.

5. Janus C, Phinney AL, Chisti MA, et al. New development in animal model of Alzheimer disease. Current Neurology and Neuroscience Reports. 2001;1(5):451-457.

6. Vickers JC. A vaccine against Alzheimer disease, development to date. Drug Aging. 2002;9(7):497-494.

7. Wisniewski T. Active Immunotherapy of Alzheimer Disease. The Lancet Neurology. 2012;11(7):571-572.

8. Lambarcht W, Rosenberg RN. Advances in the development of vaccine for Alzheimers disease. Discov Med. 2013;15(84):319-326.

9. NIH. Understanding Vaccines. 1998. 
10. Shapshak MA, Shapshak P, Fujimura R, et al. J Neuroscie. 2002;202(1-2):13-23.

11. Finch CE, Morgan TE, Rozovsky I, et al. Microglia and ageing in the brain. In: Streit WJ (eds.), Microglia in regenerating and degenerating central nervous system, Spriger-Verlag, Germany. 2002. p.275-305.

12. Rock RB, Gekker G, Hu S, et al. Role of microglia in central nervous system Infections. Clin Micribiol Rev . 2004;17(4):942-964.
13. Kreutzberg W. Microglia:Sensor for pathological Events in central nervous system. Trends Neurosci . 1996;19(8):312-318.

14. Mattson MP. Apoptosis in neurodegeneration disorders. Nat Rev Mol Cell Biol. 2000;1(2):120-130.

15. Elmore S. Apoptosis: A Review of program cell death. Toxicol pathol. 2007;35(4):495-516. 